\title{
PENGARUH IKLAN SOSIAL MEDIA TERHADAP KEPUTUSAN PEMBELIAN KONSUMEN DI LINGKUNGAN UNIVERSITAS BALI INTERNASIONAL
}

\author{
Kadek Riyan Putra Richadinata ${ }^{1}$ \\ Ni Luh Putu Surya Astitiani
1,2 Fakultas Bisnis Sosial Teknologi dan Humaniora Program Study Bisnis Digital Universitas Bali Internasional email: kejutankertas1@gmail.com

\begin{abstract}
ABSTRAK
Revolusi 4.0 merupakan tonggak awal dari lahirnya globalisasi di bidang ekonomi dunia. Pergerakan kemajuan bisnis saat ini dibarengi dengan perkembangan di bidang teknologi informasi dan komunikasi. Media sosial adalah suatu interaksi sosial antara individu dalam berbagi dan bertukar informasi. Media sosial dapat mencakup berbagai ide, pendapat, gagasan dan konten dalam komunitas virtual serta mampu menghadirkan dan mentranslasikan cara berkomunikasi baru dengan teknologi yang sama sekali berbeda dari media tradisional. Beriklan dengan media sosial bahkan menawarkan nilai jangka panjang. Penelitian ini dilakukan bertujuan untuk mengetahui pengaruh iklan sosial media (perhatian, pemahaman, penerimaan, dan penyimpanan) terhadap keputusan pembelian di lingkungan Universitas Bali Internasional. Sampel dalam penelitian ini adalah mahasiswa Universitas Bali Internasional sebanyak 96 orang dimana hasil pengumpulan data diolah menggunakan teknik analisis Regresi Berganda. Hasil penelitian membuktikan bahwa perhatian, pemahaman, penerimaan, dan penyimpanan iklan sosial media berpengaruh positif dan signifikan terhadap keputusan pembelian konsumen di lingkungan Universitas Bali Internasional. Hal ini menunjukkan keputusan pembelian dapat meningkat tidak hanya dipengaruhi oleh iklan konvensional tetapi ad tetapi adanya iklan sosial media Instagram dapat meningkatkan keputusan pembelian konsumen.

Kata Kunci: perhatian, pemahaman, penerimaan, penyimpanan
\end{abstract}

\begin{abstract}
Revolution 4.0 is the first milestone in the birth of globalization in the world economy. The current movement of business progress is accompanied by developments in the field of information and communication technology. Social media is a social interaction between individuals in sharing and exchanging information. Social media can encompass various ideas, opinions, ideas and content in virtual communities and be able to present and translate new ways of communicating with technology that is completely different from traditional media. Advertising with social media even offers long-term value. This research was conducted to determine the effect of social media advertising (attention, understanding, acceptance, and storage) on purchasing decisions at the University of Bali International. The sample in this study were 96 students at the University of Bali International where the results of data collection were processed using multiple regression analysis techniques. The results of the study prove that attention, understanding, acceptance, and storage of social media advertisements have a positive and significant effect on consumer purchasing decisions at the University of Bali International. This shows that purchasing decisions can increase not only influenced by conventional advertising but the existence of Instagram social media ads can increase consumer purchasing decisions perceptions of students can also improve the quality of higher education itself.
\end{abstract}

Keywords: attention, understanding, acceptance, storage 


\section{PENDAHULUAN}

Revolusi 4.0 merupakan tonggak awal dari lahirnya globalisasi di bidang ekonomi dunia. Pergerakan kemajuan bisnis saat ini dibarengi dengan perkembangan di bidang teknologi informasi dan komunikasi. Kemajuan yang pesat tersebut dibuktikan dengan munculnya sebuah ide-ide bisnis kreatif dan inovatif dengan berbasis teknologi. Seluruh masyarakat termasuk masyarakat yang ada di Indonesia dituntut untuk mampu mengikuti arus perkembangan dan kemajuan teknologi tersebut. Salah satu upaya pemerintah dalam memperluas wawasan terkait penggunaan teknologi yakni dengan peningkatan kesadaran masyarakat melalui pengenalan terhadap perkembangan teknologi yang saat ini sedang berkembang (Immawati dan Dadang, 2019).

Pada era revolusi industri saat ini baik pada masyarakat, organisasi maupun suatu perusahaan memiliki aktivitas yang tidak akan pernah lepas dari perkembangan teknologi dan informasi. Perkembangan teknologi informasi dan komunikasi saat ini yang begitu pesat telah menyebabkan perubahan pada berbagai sektor baik di sektor sosial, ekonomi, maupun budaya yang berlangsung dengan perlahan namun pasti. Adanya perkembangan teknologi yang sangat pesat tersebut dimanfaatkan oleh lapisan kalangan tertentu untuk menciptakan suatu inovasi teknologi baru khususnya pada bidang promosi (Yuliar, 2018). Teknologi informasi dalam dunia promosi bukanlah suatu hal yang baru kalau dilihat saat ini.

Media sosial adalah suatu interaksi sosial antara individu dalam berbagi dan bertukar informasi. Media sosial dapat mencakup berbagai ide, pendapat, gagasan dan konten dalam komunitas virtual serta mampu menghadirkan dan mentranslasikan cara berkomunikasi baru dengan teknologi yag sama sekali berbeda dari media tradisional (Watson, 2009). Perkembangan dunia teknologi yang sudah semakin inovatif di era global telah memberikan dampak langsung kepada masyarakat terutama bagi generasi muda. Media sosial dapat diakses dengan mudah melalui smartphone (telepon pintar) kapan saja dan dimana saja oleh pemiliknya. Platform media sosial sangat banyak ragamnya. Kemunculan Friendster pada tahun 2002 menjadi terobosan awal di dunia media sosial dengan hampir 1 juta pengguna. Facebook menyusul pada tahun 2006 dan disusul oleh

Platform - platform media sosial yang lain seperti twitter, path, instagram, dan snapchat. Hal tersebut membuktikan bahwa media sosial dibutuhkan oleh para pengguna smartphone di era global (Culandari, 2008).

Media Sosial kini telah menjadi trend dalam komunikasi pemasaran. Menurut Kaplan dan Haenlein (2010), media sosial adalah sekelompok aplikasi berbasiskan internet yang dibangun berdasarkan kerangka pikiran ideologi dan teknologi dari Web 2.0, dan memungkinkan terbentuknya kreasi pertukaran isi informasi dari pengguna internet. Web 2.0 adalah dasar terbentuknya sosial media (Carlsson, 2010). Contoh media sosial yang berkembang saat ini adalah: twitter, facebook, myspace, youtube, instagram, path, whatsapp, line, dll. Mengingat pentingnya informasi tentang bagaimana penggunaan media sosial bagi UKM dan manfaatnya, maka perlu dilakukan suatu penelitian observasional.

Dengan besarnya generasi baru yang akan online melalui ponsel, Indonesia diprediksi akan menjadi kontributor besar dalam miliaran pengguna internet. Maka itu, berpotensi besar pengembangan iklan melalui media sosial. Menurut 
survey eMarketer pada tahun 2013, market share iklan Google sebesar 33,6 persen turun menjadi 31,1 persen pada 2014. Sementara market share untuk iklan Facebook meningkat dari 5,8 persen pada 2013 menjadi 7,8 persen pada tahun 2014. Iklan tradisional dengan media sosial ternyata lebih canggih karena mampu mendorong traffic dan penjualan. Beriklan dengan media sosial bahkan menawarkan nilai jangka panjang. Iklan yang tampil di sosial media menciptakan konten visual yang mendorong konsumen untuk menekan tombol klik dan share sehingga pemasaran menyebar dengan sendirinya. Di samping itu ada beberapa kekuatan lain dari iklan sosmed dibanding iklan dengan mesin pencarian. Apalagi jika iklan tersebut berkonsep sosial yang mampu memancing emosi dan rasa ingin tahu dari para pengguna internet, itu bisa menjadi nilai plus yang lebih berpeluang untuk meraih sukses.Berdasarkan latar belakang di atas, peneliti tertarik untuk melakukan penelitian tentang Pengaruh periklanan sosial media terhadap keputusan pembelian konsumen mamasiswa di lingkungan Universitas Bali Internasional.

Adapun tujuan penelitian ini adalah untuk mengetahui pengaruh periklanan sosial media terhadap keputusan pembelian konsumen mahasiswa di lingkungan Universitas Bali Internasional. Untuk mengetahui pengaruh perhatian iklan sosial media terhadap keputusan pembelian konsumen mamasiswa di lingkungan Universitas Bali Internasional. Untuk mengetahui pengaruh pemahaman iklan sosial media terhadap keputusan pembelian konsumen mamasiswa di lingkungan Universitas Bali Internasional. Untuk mengetahui pengaruh penerimaan iklan sosial media terhadap keputusan pembelian konsumen mamasiswa di lingkungan Universitas Bali Internasional. Untuk mengetahui pengaruh penyimpanan terhadap keputusan pembelian konsumen mamasiswa di lingkungan Universitas Bali Internasional.

Adapun manfaat penelitian ini yaitu manfaat praktis yaitu hasil penelitian ini dapat menjadi sumber informasi bagi perusahaan pengguna iklan sosial media terhadap keputusan pembelian konsumen. Manfaat teoritis yaitu hasil penelitian bisa menjadi sumber informasi tambahan dalam memperkuat hasil-hasil studi tentang keputusan pembelian di kalangan mahasiswa.

Manajemen pemasaran adalah proses penetapan tujuan-tujuan pemasaran bagi suatu organisasi, perencanaan, dan pelaksanaan aktivitas untuk memenuhi tujuan-tujuan tersebut, dan mengukur kemajuan ke arah pencapaiannya. Globalisasi telah mendorong beberapa perusahaan untuk memasarkan di luar negara asal mereka. Menurut (Kotler \& Keller, 2013:14) menyatakan bahwa Manajemen pemasaran adalah analisis, perencanaan, pelaksanaan, dan pengendalian atas program yang dirancang untuk menciptakan, membangun, dan mempertahankan pertukaran yang menguntungkan dengan pembeli sasaran dengan maksud untuk mencapai sasaran organisasi. Berikut ini adalah elemenelemen dari bauran pemasaran dari (Morisson M.A, 2015: 5)ada beberapa, yaitu : produk, place, price, dan promotion.

Secara teori, produk merupakan segala bentuk yang ditawarkan ke pasar untuk digunakan atau dikonsumsi sehingga bisa memenuhi kebutuhan dan keinginan pasar. Keinginan pasar tersebut bisa berupa fisik, jasa, orang, organisasi dan ide. Produk adalah hasil dari kegiatan produksi perusahaan yang nantinya akan 
di jual oleh perusahaan. Atau Produk bisa jadi berupa barang yang dibeli oleh perusahaan untuk kemudian dijual kembali kepada konsumen atau customer.

Harga adalah suatu nilai tukar yang bisa disamakan dengan uang atau barang lain untuk manfaat yang diperoleh dari suatu barang atau jasa bagi seseorang atau kelompok pada waktu tertentu dan tempat tertentu. Istilah harga digunakan untuk memberikan nilai finansial pada suatu produk barang atau jasa. Dengan kata lain, konsumen akan membeli produk jika pengorbanan yang dikeluarkan (yaitu uang dan waktu) sesuai dengan manfaat yang ia ingin dapatkan dari produksi barang atau jasa yang ditawarkan oleh perusahaan tersebut.

Tempat atau wadah yang digunakan untuk memasarkan suatu produk. Place merupakan salah satu faktor penting dalam marketing mix agar pemasaran yang dilakukan dapat berjalan dengan maksimal dan produk yang ditawarkan dapat dengan mudah didapatkan oleh konsumen yang membutuhkan. Saluran distribusi yang tepat juga menentukan berhasil tidaknya strategi marketing. Oleh karena itu, saluran distribusi menempati posisi yang krusial. Adapun definisi dari saluran distribusi ini sendiri adalah berbagai kegiatan atau upaya apapun yang dilakukan oleh perusahaan untuk membuat produk atau jasanya mudah diperoleh atau tersedia di tangan konsumen maupun pelanggannya.

Promosi yang dimaksud adalah sebuah upaya persuasi (bujukan atau dorongan) untuk mengajak para konsumen maupun calon konsumen untuk membeli (atau menggunakan) produk maupun jasa yang dihasilkan oleh suatu perusahaan.

Perilaku konsumen merupakan suatu proses yang berkaitan erat dengan proses pembelian, pada saat itu konsumen melakukan aktifitas-aktifitas seperti melakukan pencarian, penelitian, dan pengevaluasian produk. Perilaku konsumen merupakan hal-hal yang mendasari konsumen untuk membuat keputusan pembelian. Menurut (Kotler \& Keller, 2013:166) perilaku konsumen adalah studi tentang bagaimana individu, kelompok, dan organisasi memilih, membeli, menggunakan, dan bagaimana barang, jasa, ide atau pengalaman untuk memuaskan kebutuhan dan keinginan mereka. Yang termasuk ke dalam perilaku konsumen selain mengenai kualitas produk, juga meliputi harga produk atau jasa tersebut. Jika harga suatu produk tidak terlalu tinggi, maka konsumen tidak akan terlalu lama membutuhkan waktu untuk memikirkan dan melakukan aktifitas perilaku konsumen. Namun jika harga suatu barang atau jasa tersebut bisa dibilang tinggi, atau mahal, maka konsumen tersebut akan memberikan effort lebih terhadap barang tersebut. Pembeli tersebut akan semakin lama melakukan perilaku konsumen, seperti melihat, menanyakan, mengevaluasi, dan mempertimbangkan.

Pengambilan keputusan sebagai proses penting yang memengaruhi peri-laku konsumen harus dipahami oleh pe-masar. Perilaku konsumen merupakan studi yang mengkaji bagaimana individu membuat keputusan untuk membelanjakan sumber daya yang ter-sedia dan dimiliki (waktu, uang, dan usaha) untuk mendapatkan barang atau jasa yang nantinya akan dikonsumsi (Suryani, 2013:6). Ada dua faktor yang memengaruhi pengambilan keputusan pembelian yang selanjutnya akan menen-tukan respons konsumen. Pertama, konsumen itu sendiri. Ada dua unsur dari konsumen yang berpengaruh te r-hadap pengambilan keputusan yaitu pikiran konsumen yang meliputi kebutuhan atau motivasi, 
persepsi, sikap dan karakteristik konsumen yang meliputi demografi, gaya hidup, dan kepribadian konsumen. Faktor kedua adalah pengaruh lingkungan yang terdiri atas nilai budaya, pengaruh sub dan lintas budaya, kelas sosial, face to face group, dan situasi lain yang menentukan (Suryani, 2013:6).

Komunikasi pemasaran di era media sosial tidak terlepas dari komunikasi pemasaran di media sosial. Dua bentuk komunikasi pemasaran di media sosial yang umum digunakan yaitu periklanan dan pemasaran. Periklanan melalui media sosial. Periklanan melalui media sosial adalah segala bentuk komunikasi nonpersonal berbayar, tentang sebuah organisasi, produk, jasa, atau ide yang menggunakan media sosial sebagai medianya (Belch, 2009). Kata "berbayar" menunjukkan bahwa sebuah pesan periklanan biasanya menggunakan media yang harus dibayar sedangkan kata "nonpersonal" menunjukkan bahwa pesan dalam periklanan disampaikkan kepada kelompok orang atau individual secara bersamaan dengan menggunakan media massa. (Wenats dkk., 2012). Pemasaran melalui media sosial. Selain iklan online, para pemasar juga menggunakan social community yang terdiri dari berbagai bentuk interaksi mulai dari forum (Kaskus atau Fashionesdaily), situs jejaring sosial (Facebook atau Instagram), dunia virtual (Second Life, There, atau Kaneva), games, situs berbagi (Flickr atau YouTube), hingga mikroblogging (Twitter). Menurut Tuten dalam Wenats (2012) pemasaran melalui media sosial adalah salah satu bentuk periklanan yang menggunakan media social community dimana pengiklan dusen atau pemilik merek) dapat langsung berinteraksi dan membangun dialog dengan para konsumennya. Menurut Taprial \& Kanwar (2012) sosial media memiliki beberapa keunggulan yang menjadikannya lebih kuat dibandingkan media tradisional: (1) Accessibility Sosial media mudah untuk diakses karena memerlukan sedikit atau tidak ada biaya sama sekali dalam penggunaanya. (2) Speed, konten yang dibuat dalam sosial media tersedia bagi semua orang yang berada dalam jaringan, forum, atau komunitas begitu diterbitkan. (3). Interactivity, media sosial dapat menampung dua atau lebih saluran komunikasi. (4). Longevity / Volativity, konten pada sosial media tetap dapat diakses pada waktu yang lama, atau bahkan selamanya. (5) Reach, Internet menawarkan jangkauan yang tidak terbatas ke semua konten yang tersedia.

(Tjiptono, 2015)menyatakan bahwa promosi merupakan salah satu faktor penentu keberhasilan suatu program pemasaran untuk memberikan informasi mengenai adanya suatu produk. Media sosial saat ini menjadi salah satu alat yang banyak digunakan oleh pemasar dalam menyebarkan informasi tentang suatu produk kepada konsumen. Jaringan sosial media ini merupakan bentuk baru dari dialog antara "consumer-to-consumer" dan "businessto-consumer" yang memiliki implikasi besar terhadap pemasar (Kotler \& Armstrong, 2017).

Hayden dan Herman (2012) menggunakan istilah red-hot, untuk menggambarkan peluang pemasar yang sedemikian besar dalam pemasaran via internet. Sosial media juga sarana komunitas online dimana orang dapat bersosialisasi dan bertukar informasi, yang bertujuan membangun hubungan dan membangun loyalitas pada konsumen. (A. Depito,2011).

Sosial media marketing memungkinkan membangun hubungan sosial yang lebih personal dan dinamis dibandingkan dengan strategi marketing tradisional. Promosi dengan menggunakan media sosial mempengaruhi keputusan pembelian. 
Hal tersebut sejalan dengan hasil penelitian yang dilakukan oleh Singgih Nurgiyantoro tahun 2014, menyebutkan bahwa promosi melalui media sosial berpengaruh positif dan signifikan terhadap keputusan pembelian konsumen dengan nilai koefisien regresi sebesar 0,792 dan keputusan pembelian dipengaruhi oleh strategi promosi melalui media sosial sebesar 34\%.

(Kotler \& Keller, 2013) mengemukakan bahwa word of mouth communication (WOM) atau komunikasi dari mulut ke mulut merupakan proses komunikasi yang berupa pemberian rekomendasi baik secara individu maupun kelompok terhadap suatu produk atau jasa yang bertujuan untuk memberikan informasi secara personal. Menurut Goyette, Ricard, Bergeron, dan Marticotte (2010) WOM didefinisikan sebagai pertukaran, aliran informasi, atau percakapan dua individu. Komunikasi dari mulut ke mulut merupakan salah satu saluran komunikasi yang sering digunakan oleh banyak perusahaan, karena komunikasi ini dinilai sangat efektif dalam memperlancar proses pemasaran dan mampu memberikan keuntungan kepada perusahaan.

Pemasaran dengan menggunakan word of mouth dapat juga disebut word of mouth marketing yaitu kegiatan pemasaran melalui perantara orang ke orang baik secara lisan, tulisan, maupun alat komunikasi elektronik yang berhubungan dengan pengalaman pembelian jasa atau pengalaman menggunakan produk atau jasa (Kotler \& Keller, 2013). Definisi lain dari word of mouth marketing menurut sumardy (2011) yaitu kegiatan pemasaran yang memicu konsumen untuk membicarakan, mempromosikan, merekomendasikan hingga menjual merek suatu produk kepada calon konsumen lainnya.

Word of mouth memiliki kekuatan besar yang berdampak pada perilaku pembelian konsumen. Rekomendasi dari teman yang sudah dipercaya, asosiasi, dan konsumen lain berpotensi untuk lebih dipercaya dibandingkan dari sumber komersil, seperti iklan dan salespeople. Sebagian besar, word of mouth terjadi secara alami, konsumen mulai dengan membicarakan sebuah merek yang mereka gunakan kepada orang lain (Kotler \& Armstrong, 2017).

Berdasarkan teori mengenai word of mouth di atas, maka dapat disimpulkan bahwa word of mouth merupakan media promosi yang dilakukan dengan perantara orang untuk menyampaikan pesan mengenai suatu nilai produk/jasa yang telah digunakan kepada orang lain dan berdampak pada penilaian terhadap produk/jasa tersebut.

Dalam penelitian yang dilakukan (Goyette et al., 2010) tentang skala pengukuran WOM, mereka mengusulkan beberapa indikator untuk mengukur WOM antara lain: (1) WOM intensity. Intensitas atau volume percakapan mengenai suatu produk yang terjadi dalam percakapan sehari-hari. (2) Positive valence WOM. Penilaian positif sebagai efek dari kepuasan yang didapatkan konsumen yang dituangkan dalam percakapan sehari-hari seperti pemberian rekomendasi atau ajakan untuk membeli suatu produk. (3) Negative valence WOM. Penyampaian hal-hal negatif kepada orang lain tentang suatu produk yang disebabkan oleh ketidakmampuan produk tersebut untuk memenuhi ekspektasi konsumen. (4) WOM Content. Isi percakapan atau konten pembahasan suatu produk seperti jenis, kualitas, harga, dan lain-lain.

Word of mouth yang dilakukan oleh konsumen merupakan salah satu hal 
yang harus diperhatikan oleh perusahaan karena sesuatu yang dibicarakan oleh konsumen mengenai suatu produk akan berimbas pada citra produk atau perusahaan tersebut, maka perusahaan harus dapat merangsang konsumen agar termotivasi untuk melakukan pembicaraan yang positif tentang produk atau perusahaan.

Konsumen yang termotivasi akan secara otomatis melakukan pembicaraan mengenai suatu produk. Octovate Consulting Group (Sriwedari, 2011) mengembangkan word of mouth dalam tiga tahapan, yaitu: Talking. Tahap awal dimana pemilik merk harus dapat mengidentifikasi talkers yang tepat dan menyediakan topik yang menarik untuk dibicarakan. Promoting. Tersedianya tools untuk talkers agar dapat dibagikan dan disebarkan kepada orang lain. Selling. Bagaimana agar bisa untuk mempengaruhi orang untuk "menjual" dan mempromosikan produk tersebut.

Perusahaan harus mampu mengubah persepsi bahwa Word Of Mouth hanyalah pembicaraan yang menarik saja, word of mouth bisa lebih dari itu. Disini suatu produk tidak sekedar dibicarakan dan dipromosikan, tetapi lebih dari itu, kegiatan word of mouth harus mampu mengubah perilaku konsumen, dari yang tidak membeli menjadi membeli dan dari yang berfikir skeptis menjadi tertarik untuk mencoba (Sumardy dkk., 2011).

Iklan merupakan salah satu media komunikasi pemasaran yang kerap digunakan dalam aktivitas ekonomi dalam upaya mengenalkan produk kepada konsumen. Situasi pasar yang kompetitif menjadikan tidak ada suatu bisnis yang mampu bertahan lama tanpa didukung oleh bauran komunikasi pemasaran semisal iklan yang efektif dan efisien. Iklan sebagai salah satu sarana pemasaran produk barang atau jasa harus mampu tampil menarik dan persuasive Jefkins, Frank (2012) Tentu ketika kita melihat semakin bertambahnya jumlah penduduk maka meniscayakan pula semakin besarnya kebutuhan masyarakat dalam kehidupan seharihari.Hal tersebut menjadi suatu konsekuensi bagi para produsen yang hadir dalam upaya untuk menjawab pemenuhan kebutuhan masyarakat melihat hadirnya persaingan diantara berbagai perusahaan terkait.Salah satu jalan yang ditempuh oleh perusahaan adalah dengan kemampuan mengelola dan menyampaikan informasi kepada konsumen terkait produknya melalui aktivitas periklanan. Iklan yang berarti pesan yang menawarkan suatu produk yang ditujukan kepada masyarakat melalui suatu media, Kasili dan Renal (2013).

Pembahasan Iklan Sebagai Komunikasi Pemasaran Konsep paling pokok yang melandasi pemasaran adalah kebutuhan manusia. Dengan adanya perkembangan jaman, kebutuhan berkembang menjadi suatu keinginan mengkonsumsi suatu produk dengan ciri khas tertentu. Munculnya keinginan akan suatu menciptakan permintaan spesifik terhadap suatu jenis produk. Seseorang dalam menentukan keputusan pembelian akan mempertimbangkan nilai dan kepuasan yang akan didapat dari mengkonsumsi suatu produk. Apabila konsumen yakin akan nilai dan kepuasan yang akan didapat, maka konsumen akan melalukan pertukaran dan transaksi jual beli barang dan jasa.

Keputusan Pembelian Sebagai Perilaku Konsumen Terdapat beberapa definisi perilaku konsumen yang dikemukakan oleh para pakar, Swastha dkk. (2015) perilaku konsumen ialah tindakan yang langsung terlibat untuk 
mendapatkan, mengkonsumsi dan menghabiskan produk atau jasa, termasuk proses keputusan yang medahului dan mengikuti tindakan tersebut.Lalu menurut Mulyana, Deddy (2014) lebih menekankan perilaku konsumen sebagai suatu proses pengambilan keputusan yang menyaratkan kepada individu untuk mengevaluasi,memperoleh,serta 4 menggunakan atau mengatur barang dan jasa. (Kotler \& Keller, 2016) mengartikan perilaku konsumen sebagai perilaku pembelian konsumen akhir baik individu maupun rumah tangga yang membeli produk untuk konsumsi personal.

Dikutip dari Junidah Alfianasari (2010) keputusan pembelian konsumen merupakan sikap konsumen dalam menentukan arah dan tujuan akhir dalam proses pembelian suatu produk. Hubungan Iklan Dan Pengambilan Keputusan Pembelian Konsumen Konsumen menganggap bahwa iklan sebagai jendela informasi sebagai paduan dalam memilih produk. Di lingkungan produsen, iklan merupakan media promosi tentang kualitas dan ciri-ciri produk kepada masyarakat baik orang tua maupun anak-anak. Sebagai calon konsumententu perlu informasi yang jelas terhadap produk yang diiklankan. Melalui informasi yang jelas niscaya calon konsumen akan mempunyai keputusan untuk membeli. Liliweri, Alo (2014)

Iklan merupakan salah satu bentuk khusus komunikasi yang biasanya digunakan pengusaha untuk mengarahkan komunikasi persuasi pada pembeli sasaran dan masyarakat. Menurut Swastha (2002:248) periklanan merupakan suatu alat untuk membuka komunikasi dua arah antara penjual dengan pembeli, sehingga keinginan mereka dapat terpenuhi dengan cara yang efisien dan efektif. Salah satu strategi dalam periklanan adalah menyeleksi media periklanan (Kotler \& Keller, 2013:161). Memilih media periklanan ditentukan berdasarkan Frekuensi, jangkauan konsumen, dan dampak yang ditimbulkan dari iklan tersebut terhadap konsumen. Setiap media periklanan memiliki kelebihan dan kekurangan masing masing dalam mengiklankan sebuah produk. Sebagai seorang pemasar harus dapat memilih media periklanan dengan tepat sehingga iklan dapat sampai pada konsumen dengan efektif dan efisien. Televisi merupakan salah satu media periklanan yang sering digunakan oleh pemasar dalam mengiklankan produknya.

Menurut Ivancevich et al. (2006:87) sikap merupakan perilaku yang disebabkan karena keduannya berhubungan dengan persepsi, kepribadian, perasaan, dan motivasi. Menurut Lamb et al. (2001:233) sikap merupakan suatu kecenderungan yang dipelajari untuk memberikan sebuah respon secara konsisten terhadap suatu objek yang diberikan, seperti halnya sebuah produk tertentu. Menurut Suryani (2013:121) sikap dibentuk dari tiga komponen, yaitu

1) Komponen Kognitif Suatu hal yang diketahui individu atau pengalaman individu baik secara langsung atau tidak langsung dengan objek sikap. Sikap kognitif dipengaruhi oleh pengalaman, pengamatan serta informasi yang diperoleh mengenai objek sikap.

2) Komponen Afektif Komponen yang berkenaan dengan perasaan dan emosi konsumen mengenai objek sikap. Komponen ini beragam ekspresinya mulai dari rasa sangat tidak suka hingga sangat suka. Perasaan konsumen terhadap suatu objek sikap dipengaruhi oleh kognisinya. Seorang konsumen sangat suka dengan suatu produk atau merek karena mereka memiliki pengetahuan, informasi yang positif tentang produk atau merek tersebut. 
3) Komponen Konatif Komponen ini berkenaan dengan kecenderungan individu untuk melakukan tindakan dengan objek sikap. Komponen ini bukan perilaku nyata, namun masih berupa keinginan untuk melakukan suatu

Keputusan untuk membeli yang diambil oleh konsumen merupakan kumpulan dari beberapa keputusan. Menurut Swastha dan Irawan (2001:118) setiap keputusan membeli mempunyai 7 komponen dalam struktur pembelian, yaitu: 1) Keputusan tentang jenis produk Konsumen dapat mengambil keputusan untuk membeli sejumlah produk tertentu atau menggunakan uangnya untuk tujuan lain. 2) Keputusan tentang bentuk produk Konsumen dapat mengambil keputusan untuk membeli bentuk produk tertentu. 3) Keputusan tentang merek Konsumen harus mengambil keputusan tentang merek mana yang akan dibeli, dimana setiap merek memiliki perbedaan. 4) Keputusan tentang penjualannya Konsumen harus mengambil keputusan dimana produk tersebut akan dibeli. 5) Keputusan tentang jumlah produk Konsumen dapat mengambil keputusan tentang seberapa banyak produk yang akan dibelinya. 6) Keputusan tentang waktu pembelian Konsumen dapat mengambil keputusan tentang kapan ia harus melakukan pembelian. 7) Keputusan tentang cara pembayaran Konsumen harus mengambil keputusan tentang metode atau cara pembayaran produk yang akan dibeli, baik secara tunai maupun angsuran. Hubungan Iklan dengan Sikap Konsumen Pada dasarnya dalam mengiklankan sebuah poduk adalah untuk mempengaruhi sikap khalayak, dalam hal ini tentunya sikap dari konsumen (Jefkins, 1996:17). Meskipun periklanan tidak dapat merubah nilai dan sikap konsumen yang telah berakar dalam, akan tetapi periklanan dapat merubah sikap negatif seseorang terhadap produk menjadi positif (Lamb et al., 2001:204).

Menurut Suryani (2013:129) faktor pembentukan sikap yaitu dengan promosi produknya kepada konsumen melalui media iklan yang bersifat massal seperti televisi. Penelitian yang dilakukan oleh Khasanah (2012) dan Qolby (2014) menyatakan bahwa iklan sebagai salah satu variabel yang berpengaruh dalam pembentukan sikap konsumen. Promosi melalui iklan dari suatu produk yang efektif dapat menampilkan keunggulan atau manfaat secara baik, serta dapat menimbulkan sikap yang positif terhadap produk tersebut dan sebaliknya, jika promosi kurang baik maka akan menimbulkan sikap negatif terhadap produk tersebut (Lasfita, 2015). Berdasarkan penjelasan tersebut dapat disimpulkan bahwa terdapat hubungan antara kegiatan periklanan yang dilakukan oleh perusahaan tehadap sikap konsumen.

Menurut (Tjiptono, 2015) iklan merupakan bentuk komunikasi tidak langsung, yang didasar pada informasi tentang keunggulan dan keuntungan suatu produk. Berkaitan dengan keputusan pembelian Lamb et al. (2001:192) menjelaskan bahwa empat variabel dari bauran promosi dapat mempengaruhi konsumen dalam membuat keputusan pembelian, yang mana salah satu variabelnya adalah periklanan.

Penelitian (Wibowo, 2011) menyatakan bahwa variabel iklan televisi berpengaruh secara positif dan signifikan terhadap keputusan pembelian konsumen. Selain itu, pada penelitian Febriana (2015) menyatakan bahwa variabel iklan televisi berpengaruh positif terhadap keputusan pembelian namun tidak signifikan.Berdasarkan penjelasan tersebut dapat disimpulkan bahwa terdapat 
hubungan antara periklanan yang dilakukan oleh perusahaan tehadap keputusan pembelian konsumen.

Menurut Simamora (2004:152) pengambilan keputusan pembelian berkaitan erat dengan perilaku konsumen, sikap merupakan konsep paling penting. Hal tersebut dikarenakan untuk memasarkan sebuah produk, seorang pemasar perlu mengetahui perilaku pembelian konsumen. Menurut (Kotler \& Keller, 2013:184) keyakinan dan sikap memengaruhi perilaku pembelian dalam proses evaluasi dari keputusan pembelian. Penelitian yang dilakukan oleh Wahyuni (2008) dan Saputra (2013) yang membahas variabel sikap konsumen sebagai salah satu faktor yang mempengaruhi konsumen secara positif dalam keputusan pembelian konsumen atas suatu produk. Sikap sangat erat hubungannya dengan perasaan suka dan tidak suka seseorang, apabila konsumen merasa suka dengan produk tersebut maka konsumen akan membeli produk tersebut, Begitu pula sebaliknya. Berdasarkan penjelasan tersebut dapat disimpulkan bahwa terdapat hubungan antara sikap konsumen tehadap keputusan pembelian konsumen.

Theory of planned behavior disebut juga teori perilaku rencanaan merupakan pengembangan lebih lanjut dari theory of reasoned action (TRA). Model TPB dikembangkan oleh Ajzen pada tahun 1988 dan TPB memiliki asumsi dasar yakni banyak perilaku tidak semuanya dibawah kontrol penuh individual sehingga perlu ditambahkan konsep kontrol perilaku atau perceived behavioral control (PBC) (Jogiyanto, 2008). Tambahan konsep tersebut merupakan perbedaan utama antara model TPB dan TRA, sehingga bentuk modelnya menjadi seperti gambar dibawah ini.

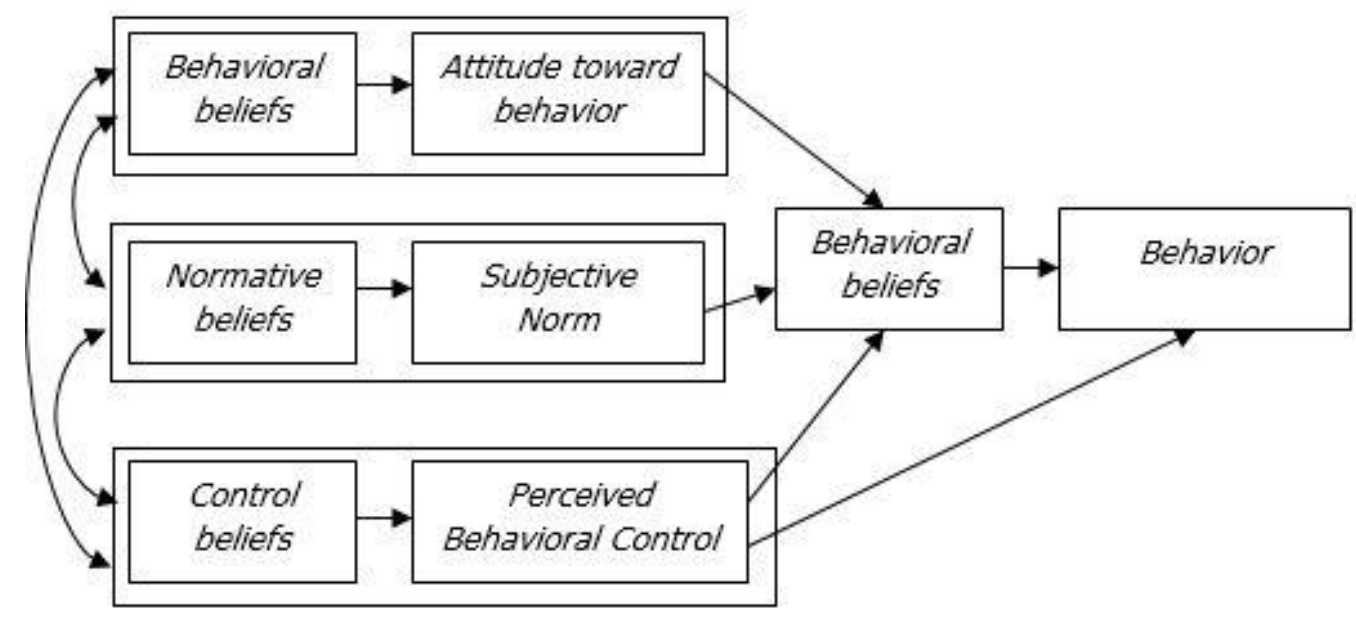

Gambar 1. Model Theory of planned behavior

Dari model di atas, dapat dibaca bahwa kepercayaan perilaku (behavioral beliefs) memproduksi suatu sikap (attitude) menyukai atau tidak menyukai terhadap perilaku. Kepercayaan normatif (normative beliefs) menghasilkan tekanan sosial atau norma-norma subjektif (subjective norm). Kepercayaan kontrol (control beliefs) akan memberikan kontrol perilaku (perceived behavioral control). Kemudian attitude, subjective norm dan perceived behavioral control secara bersama-sama akan mengakibatkan minat perilaku (behavioral intention) yang selanjutnya akan menimbulkan perilaku (behavior). Kontrol perilaku 
(perceived behavioral control) didefinisikan sebagai kemudahan atau kesulitan yang dirasakan untuk melakukan suatu perilaku (Jogiyanto, 2008). Seperti terlihat pada gambar bahwa PBC dipengaruhi oleh control beliefs atau kepercayaan kontrol. Kepercayaan kontrol adalah kepercayaan-kepercayaan yang dimiliki individual mengenai sumber daya dan kesempatan-kesempatan yang dimilikinya untuk mengantisipasi halangan yang dihadapinya (Jogiyanto, 2008).

Pengertian Sosial Media yaitu dengan berkembangnya teknologi, media promosi semakin bertambah salah satunya melalui media internet dengan menggunakan media ini perusahaan tidak membutuhkan banyak biaya untuk mempromosikan produk, jangkauannya pun lebih luas. Pengertian media sosial adalah segala bentuk media komunikasi interaktif yang memungkinkan terjadinya interaksi dua arah dan umpan balik (M.L. Kent, 2013).

Pengertian iklan melalui social media adalah sebagai media baru untuk menjangkau konsumen kini suatu perusahaan menggunakan iklan melalui social media sebagai sarana promosi untuk mempermudah memperkenalkan produk baru kepada konsumen.

Keputusan pembelian adalah tahap berikutnya setelah adanya niat atau keinginan membeli. Tetapi keputusan pembelian berbeda dengan pembelian sebenarnya (Morisson M.A, 2015). Ketika konsumen memilih untuk membeli suatu merek, ia masih harus melaksanakan keputusan dan melakukan pembelian sebenarnya. Ada keputusan tambahan yang diperlukan yaitu: kapan membeli, dimana membeli, dan berapa banyak biaya yang dikeluarkan. Sering terjadi, ada penundaan antara keputusan pembelian dan pembelian sebenarnya, biasanya produk konsumsi jangka panjang, pembelian mobil, komputer.

Konsumen manganggap bahwa iklan sebagai jendela informasi sebagai paduan dalam memilih produk. Di lingkungan perusahaan iklan merupakan media promosi efektif untuk mengelkan produk kepada masyarakat. Sebagai calon pembeli tentunya konsumen perlu mengetahui informasi yang jelas tentang produk yang di iklankan. Melalui informasi yang ada dan jelas pastinya konsumen akan mempunyai keputusan untuk membeli.

Berkembangnya ilmu pengetahuan dan teknologi berhasil merubah pola hidup dan sistem pemasaran ekonomi di dalam masyarakat sehingga secara tidak langsung kemajuan teknologi dalam sistem pembayaran secara bertahap mampu mengganti penggunaan media cetak sebagai alat promosi yang lebih efektif dan efisien. Salah satu sistem pemasaran yang ada di era digital saat ini adalah penggunaan aplikasi instagram feeds sebagai salah satu Digital Marketing. Instagram merupakan layanan media informasi aplikasi digital yang berfungsi sebagai alat tukar menukar informasi dalam secara online.

Ada beberapa yang mempengaruhi penggunaan iklan instagram media sosial sebagai salah satu aplikasi dalam sistem promosi di kalangan pengusaha termasuk mahasiswa. Faktor yang dapat mempengaruhi keputusan pembelian melalui iklan sosial media antara lain media yang sesuai, perhatian, pemahaman, menerimaan, dan penyimpanan sedangkan pengukuran keputusan pembelian online terhadap iklan sosial media dilihat dari keputusan tentang jenis produk, keputusan tentang bentuk produk, keputusan tentang merek, keputusan tentang penjualnya, keputusan tentang jumlah produk, keputusan tentang waktu pembelian, keputusan 
tentang cara pembayaran.

\section{METODE PENELITIAN}

Penelitian ini merupakan penelitian observasional analitik melalui pendekatan cross sectional yaitu variabel penelitian diukur atau dikumpulkan dalam satu waktu artinya mengadakan pengamatan hanya sekali terhadap beberapa variabel dan waktu bersamaan. Lokasi penelitian adalah Universitas Bali Internasional. Pengambilan data penelitian dilaksanakan selama 2 bulan yakni bulan Juni sampai bulan Juli 2020. Ruang lingkup penelitian adalah Bisnis Digital yang berkaitan tentang promosi online media sosial terhadap keputusan pembelian konsumen (instagram). Penelitian ini mengetahui tentang pengaruh iklan media sosial terhadap keputusan pembelian konsumen di lingkungan Universitas Bali Internasional.

Populasi target penelitian ini adalah mahasiswa sedangkan populasi terjangkaunya adalah mahasiswa Universitas Bali Internasional. Sampel adalah bagian dari populasi yang dipilih dengan cara tertentu sehingga dianggap dapat mewakili populasinya (Sudigdo; \& S., 2008). Mahasiswa yang dijadikan sampel tersebut sebelumnya harus memenuhi kriteria inklusi dan eksklusi. Adapun kriteria inklusinya adalah sebagai berikut : (1) Mahasiswa yang masih aktif di lingkungan Universitas Bali Internasional (2) Mahasiswa yang bersedia menjadi responden yang dibuktikan dengan penandatanganan formulir persetujuan responden. Kriteria eksklusinya adalah Mahasiswa yang mengambil cuti akademik.

Proporsi populasi yang digunakan adalah pasien rawat inap yang menggunakan JKN yaitu $p=0.5$. Sedangkan tingkat presisi yang diinginkan yaitu $\mathrm{d}=0.1$. Tingkat kepercayaan yang digunakan yaitu $\mathrm{Z}=1.96$ sehingga didapat besar sampel penelitian ini adalah sebagai berikut: 0,9604 yaitu 96 sampel.

Tehnik pengambilan sampel di masing-masing program studi Universitas Bali Internasional dilakukan secara Consecutive Sampling yakni semua mahasiswa selama periode pengumpulan data dan memenuhi kriteria inklusi, diikutsertakan dalam penelitian sampai jumlah sampel terpenuhi dengan menggunakan kuesioner terstruktur.

Instrumen yang digunakan dalam penelitian ini adalah kuesioner yang berisi pertanyaan terstruktur untuk mengukur variabel yang diteliti yaitu berisikan tentang karakteristik sosio-demografis (umur, jenis kelamin, status dan pekerjaan), faktor perhatian iklan media sosial, pemahaman iklan media sosial, penerimaan iklan media sosial, penyimpanan iklan media sosial, keputusan pembelian berdasarkan beberapa dimensi yakni keputusan tentang jenis produk, keputusan tentang bentuk produk, keputusan tentang merek, keputusan tentang penjualnya, keputusan tentang jumlh produk, keputusan tentang waktu pembelian dan keputusan tentang cara pembeyaran.

Pengumpulan data dimulai dari pengurusan ijin dan administrasi lainnya yang dibutuhkan. Pengumpulan data primer dilakukan dengan merekrut 2 orang tenaga interviewer (pewawancara) dari mahasiswa yang dikoordinir oleh peneliti kemudian dilakukan pelatihan pengisian kuesioner untuk penyamaan persepsi antara peneliti dan pewawancara serta dilakukan uji coba survei oleh interviewer (pewawancara) kepada beberapa mahasiswa. Tenaga interviewer (pewawancara) 
mendapatkan insentif selama proses penelitian. Data primer dikumpulkan oleh peneliti bersama interviewer dengan melakukan wawancara dengan menggunakan kuesioner terstruktur kepada responden/mahasiswa.

Tabel 1.

Definisi Operasional Variabel

\begin{tabular}{|c|c|c|c|c|}
\hline Variabel & Subvariabel & $\begin{array}{c}\text { Definisi Operasional } \\
\text { Variabel }\end{array}$ & $\begin{array}{c}\text { Cara dan Alat } \\
\text { Ukur }\end{array}$ & Skala Data \\
\hline \multirow[t]{4}{*}{$\begin{array}{l}\text { Karakteristik } \\
\text { Soio- } \\
\text { Demografis }\end{array}$} & Jenis Kelamin & Jenis kelamin responden & $\begin{array}{l}\text { Wawancara } \\
\text { dengan } \\
\text { kuesioner }\end{array}$ & $\begin{array}{l}\text { Nominal } \\
\text { a. Laki laki } \\
\text { b. Perempuan }\end{array}$ \\
\hline & Umur & $\begin{array}{l}\text { Umur responden yang } \\
\text { dihitung sejak tanggal } \\
\text { kelahiran sampai pada } \\
\text { saat pengisian kuesioner }\end{array}$ & $\begin{array}{l}\text { Wawancara } \\
\text { dengan } \\
\text { kuesioner }\end{array}$ & $\begin{array}{l}\text { Ordinal } \\
\text { a. Muda } \\
\text { b. Dewasa }\end{array}$ \\
\hline & Pekerjaan & $\begin{array}{l}\text { Jenis pekerjaan } \\
\text { responden }\end{array}$ & $\begin{array}{l}\text { Wawancara } \\
\text { dengan } \\
\text { kuesioner }\end{array}$ & $\begin{array}{l}\text { Nominal } \\
\text { a. } \quad \text { Bekerja } \\
\text { b. } \\
\begin{array}{ll}\text { Tidak } \\
\text { Bekerja }\end{array}\end{array}$ \\
\hline & $\begin{array}{l}\text { Status } \\
\text { mahasiswa }\end{array}$ & $\begin{array}{l}\text { Status mahasiswa sesuai } \\
\text { dengan KTP }\end{array}$ & $\begin{array}{l}\text { Wawancara } \\
\text { dengan } \\
\text { kuesioner }\end{array}$ & $\begin{array}{l}\text { Nominal } \\
\text { a. Menikah } \\
\text { b. Belum } \\
\\
\text { menikah }\end{array}$ \\
\hline \multirow[t]{4}{*}{$\begin{array}{l}\text { Iklan } \\
\text { Media } \\
\text { Sosial }\end{array}$} & Perhatian & $\begin{array}{l}\text { Perhatian Pelanggan } \\
\text { Terhadap Iklan } \\
\text { Di sosial media }\end{array}$ & $\begin{array}{l}\text { Wawancara } \\
\text { dengan } \\
\text { kuesioner }\end{array}$ & $\begin{array}{l}\text { Nominal } \\
\text { a. iya } \\
\text { b. Tidak }\end{array}$ \\
\hline & Pemahaman & $\begin{array}{l}\text { Pemahaman Pelanggan } \\
\text { Terhadap Iklan } \\
\text { Di sosial media }\end{array}$ & $\begin{array}{l}\text { Wawancara } \\
\text { dengan } \\
\text { kuesioner }\end{array}$ & $\begin{array}{l}\text { Nominal } \\
\text { a. iya } \\
\text { b. Tidak }\end{array}$ \\
\hline & Penerimaan & $\begin{array}{l}\text { Penerimaan Pelanggan } \\
\text { Terhadap Iklan } \\
\text { Di sosial media }\end{array}$ & $\begin{array}{l}\text { Wawancara } \\
\text { dengan } \\
\text { kuesioner }\end{array}$ & $\begin{array}{l}\text { Nominal } \\
\text { a. iya } \\
\text { b. Tidak }\end{array}$ \\
\hline & Penyimpanan & $\begin{array}{l}\text { Penyimpanan } \\
\text { Pelanggan } \\
\text { Terhadap Iklan } \\
\text { Di sosial media }\end{array}$ & $\begin{array}{l}\text { Wawancara } \\
\text { dengan } \\
\text { kuesioner }\end{array}$ & $\begin{array}{l}\text { Nominal } \\
\text { a. iya } \\
\text { b. Tidak }\end{array}$ \\
\hline $\begin{array}{l}\text { Keputusan } \\
\text { pembelian }\end{array}$ & & $\begin{array}{l}\text { Kepuasan mahasiswa } \\
\text { yang dilihat dari kinerja, } \\
\text { ciri ciri istimewa, } \\
\text { kehandalan, kesesuaian } \\
\text { dengan spesifikasi, daya } \\
\text { tahan, serviceability, } \\
\text { estetika dan kualitas }\end{array}$ & $\begin{array}{l}\text { Wawancara } \\
\text { dengan } \\
\text { kuesioner }\end{array}$ & \begin{tabular}{ll}
\multicolumn{2}{c}{ Nominal } \\
a. & Puas \\
b. & Tidak \\
& Puas
\end{tabular} \\
\hline
\end{tabular}

Sumber : Penelitian Sebelumnya

Analisis kuantitatif dan uji statistik yang dilakukan dalam penelitian ini dilakukan dengan cara Analisis Univariat dan Analisis Bivariat. Analisis Univariat 
dilakukan pada setiap variabel penelitian yaitu status kepesertaan, karakteristik sosio-demografis, faktor perhatian iklan media sosial, pemahaman iklan media sosial, penerimaan iklan media sosial, penyimpanan iklan media sosial, keputusan pembelian berdasarkan beberapa dimensi yakni keputusan tentang jenis produk, keputusan tentang bentuk produk, keputusan tentang merek, keputusan tentang penjualnya, keputusan tentang jumlah produk, keputusan tentang waktu pembelian dan keputusan tentang cara pembeyaran. Data dianalisa menggunakan statistik deskriptif untuk mendapatkan hasilnya dalam bentuk tabel distribusi frekuensi berupa proporsi atau persentase (\%) dari masing-masing variabel yang dilengkapi dengan narasi untuk menjelaskan tabel yang dihasilkan. Analisis Bivariat bertujuan untuk menilai faktor faktor iklan media sosial terhadap keputusan pembelian mahasiswa di Universitas Bali Internasional.

\section{HASIL DAN PEMBAHASAN}

Analisis univariat dilakukan untuk mengetahui gambaran distribusi dari setiap variabel yang diteliti. Variabel yang diteliti meliputi karakteristik sosiodemografis, iklan media social dan keputusan pembelian.

Tabel 2.

Distribusi Frekuensi Responden berdasarkan Karakteristik Sosio Demografis pada mahasiswa Universitas Bali Internasional

\begin{tabular}{clcc}
\hline No & $\begin{array}{c}\text { Karakteristik } \\
\text { Responden }\end{array}$ & $\mathbf{n}$ & $\mathbf{\%}$ \\
\hline 1 & Jenis Kelamin & & \\
& Laki-laki & 45 & 46,88 \\
& Perempuan & 51 & 53,12 \\
& Total & 96 & 100 \\
& Umur & & 15,62 \\
& $<20$ tahun & 15 & 84,38 \\
& $\geq 20$ tahun & 81 & 100 \\
& Total & 96 & 10,42 \\
3 & Pekerjaan & 10 & 89,58 \\
& Bekerja & 86 & 100 \\
& Tidak Bekerja & 96 & 0 \\
& Total & & 100 \\
& Status Mahasiswa & 0 & 100 \\
& Menikah & 96 & \\
& Belum Menikah & 96 & \\
& Total & &
\end{tabular}

Sumber: Data diolah, 2020

Berdasarkan Tabel 2. Dapat dilihat distribusi rsponden berdasarkan karakteristik sosio demografis pada mahasiswa universitas bali internasional yaitu jenis kelamin, umur, pekerjaan dan status mahasiswa. Dari 96 responden diketahui bahwa dari 45 responden $(53,12 \%)$ berjenis kelamin laki-laki dan sebanyak 51 responden $(53,12 \%)$ berjenis kelamin perempuan. Berdasarkan kategori umur sebanyak 15 responden $(15,62 \%)$ umur mahasiswa $<20$ tahun sedangkan sebanyak 81 responden $(84,38 \%)$ umur mahasiswa $\geq 20$ tahun. Berdasarkan pekerjaan, hanya sebanyak 10 responden $(10,42 \%)$ mahasiswa Universitas Bali Internasional bekerja 
sedangkan sisanya sebanyak 86 responden $(89,58 \%)$ mahasiswan tidak bekerja. Status mahasiswa Universitas Bali Internasional keseluruhan belum menikah yaitu sebanyak 96 responden $(100 \%)$.

Tabel 3.

Distribusi Frekuensi Responden berdasarkan Iklan Media Sosial

\begin{tabular}{clcc}
\hline No & \multicolumn{1}{c}{$\begin{array}{c}\text { Karakteristik } \\
\text { Responden }\end{array}$} & $\mathbf{n}$ & $\mathbf{\%}$ \\
\hline 1 & Perhatian & 80 & \\
& Iya & 16 & 83,33 \\
& Tidak & 96 & 16,67 \\
& Total & & 100 \\
& Pemahaman & 55 & 57,29 \\
& Iya & 41 & 42,71 \\
& Tidak & 96 & 100 \\
& Total & & 75 \\
3 & Penerimaan & 72 & 25 \\
& Iya & 24 & 100 \\
& Tidak & 96 & 71,88 \\
& Total & 69 & 28,12 \\
& Penyimpanan & 27 & 100 \\
\hline
\end{tabular}

Sumber: Data diolah, 2020

Berdasarkan hasil penelitian dapat dilihat pada Tabel 3. Sebanyak 80 responden $(83,33 \%)$ menyatakan memperhatikan iklan di social media. Rata-rata mahasiswa Universitas Bali Internasional hamper memahami ilkan di social media yaitu sebanyak 55 responden (57,29\%). Sedangkan sebanyak 72 responden (75\%) mahasiswa menerima iklan yang terdapat di social media, begitu pula sebanyak 69 responden $(71,88 \%)$ mahasiswa melakukan penyimpanan terhadap iklan di sosial media.

Tabel 4.

Distribusi Frekuensi Responden berdasarkan Keputusan Pembelian

\begin{tabular}{clcc}
\hline No & \multicolumn{1}{c}{$\begin{array}{c}\text { Karakteristik } \\
\text { Responden }\end{array}$} & $\mathbf{n}$ & $\mathbf{\%}$ \\
\hline 1 & Keputusan Pembelian & 66 & \\
& Puas & 30 & 68,75 \\
& Tidak Puas & 96 & 31,25 \\
& Total & 100 \\
\hline
\end{tabular}

Sumber: Data diolah, 2020

Berdasarkan distribusi frekuensi responden Tabel 4. Dapat dilihat bahwa $68,75 \%$ atau sebanyak 66 responden mahasiswa Universitas Bali Internasional merasa puas atas keputusan pembeliannya. Hal ini berarti Iklan di sosial media dapat mempengaruhi kepuasan dalam keputusan pembelian mahasiswa Universitas Bali Internasional.

Salah satu kunci sukses bagi seluruh bisnis dengan mengenal pelanggannya lebih dekat. Sosial media membuat proses pengenalan ini menjadi lebih mudah 
dibandingkan dengan sebelumnya. Dengan perangkat pendukung yang ada, kini bisa mengetahui dengan terperinci mengenai siapa saja konsumen, 203nstag yang mereka gunakan, rentang usia, bahkan jenis kelamin dari sosial media. Informasi ini dapat membantu proses branding dan promosi kepada target konsumen yang tepat. Manfaatkan juga trend usia pengguna pada masing-masing sosial media, sebagai acuan dalam memilih chanel promosi. Dengan target konsumen yang tepat diharapkan memberikan keuntungan lebih dari investasi yang telah dilakukan.

Geo-targetting merupakan 203nstagr yang efektif bila ingin mengirimkan pesan kepada target konsumen secara spesifik berdasarkan lokasi mereka. Sosial media seperti Facebook dan Twitter memiliki perangkat pendukung yang membantu untuk menyajikan informasi yang sesuai bagi konsumen. Contohnya jika memiliki bisnis perjalanan wisata dan ingin melakukan promosi melalui 203nstagram, postingan foto bisa dilengkapi dengan fitur location atau \#hashtag. Manfaatkan fitur location Instagram untuk memasarkan bisnis dengan lebih tertarget. Dengan demikian, audiens yang ingin mengunjungi lokasi wisata tersebut bisa tertarik dan memiliki kemungkinan untuk menjadi konsumen.

Sosial media seperti Instagram membantu bisnis kecil untuk menemukan konsumen dan mencari konsumen yang potensial. Jika ingin mencari konsumen dengan lokasi yang berdekatan, pencarian berdasarkan lokasi terdekat bisa dilakukan dengan Instagram. Selanjutnya akan menemukan calon konsumen yang bisa dihubungi sehubungan dengan promosi bisnis. Bisa menggunakan fitur location agar mudah ditemukan calon konsumen yang dekat dengan lokasi bisnis. Lalu untuk mencari konsumen, seperti sebelumnya bisa memanfaatkan \#hashtags yang terkait dengan bisnis, kemudian gunakan untuk menemukan calon konsumen yang sesuai. Follow/like/comment postingan mereka agar mereka bisa tahu mengenai produk/brand. Dimana pun berada, baik dalam maupun luar negeri, selama calon konsumen memanfaatkan sosial media yang sama, maka kedua pihak dapat tetap bertemu dan melakukan transaksi.

Sosial media untuk bisnis memberikan akses kepada feedback positif maupun 203nstagra dari konsumen, yang merupakan informasi berharga dari sudut pandang konsumen. Sebagai contoh, jika meluncurkan produk baru dan di bagikan melalui sosial media, maka secara instan bisa langsung mengetahui pendapat konsumen. Cara lain untuk mengetahui perspektif konsumen adalah dengan mempelajari bagaimana cara mereka menggunakan produk. Dengan adanya Fanpage pada Facebook misalnya, konsumen bisa langsung memberikan saran/kritik/pertanyaan pada kolom komentar atau mengirim pesan mengenai produk/layanan. Dengan begini respon konsumen terhadap aspek apapun pada bisnis bisa terlihat dengan jelas. Hasilnya bisa gunakan untuk melakukan improvisasi terhadap kualitas bisnis.

Dengan sosial media bisa mendapatkan informasi penting dari 203nstagram203, yang kemudian dapat meningkatkan strategi pemasaran. Dengan 203nstagra, bisa menganalisa 203nstag apa saja yang digunakan oleh 203nstagram203 dan melakukan hal yang lebih baik dari yang mereka lakukan. Selain itu juga bisa menggunakan sosial media untuk 203nstag pemasaran yang sedikit nakal, yaitu untuk melihat kelebihan \& kekurangan 203nstagram203. Caranya, cari 203nstagram203 atau pendahulu di 203nstagra bisnis, lalu perhatikan 203nstag apa saja yang mereka gunakan. Begitu juga bisa melihat siapa saja 
follower 204nstagram204, perhatikan apa yang mereka posting dan apa yang mereka sukai. Dengan demikian bisa memulai untuk mengembangkan konten yang relevan dengan target audiens dan mendapatkan klien dengan media sosial.

Salah satu keuntungan terbesar dari sosial media bagi bisnis adalah meningkatkan jumlah pengunjung website. Namun tidak hanya kunjungan yang bisa dapatkan. Apabila informasi yang mereka temukan pada website bermanfaat, mereka akan melakukan 'share' di sosial media. Ini merupakan contoh campaign dari Airbnb yang dishare melalui Twitter, mendapatkan 32 retweet dan 104 likes. Jika diperhatikan pada akhir tweet terdapat URL ke website Airbnb. Salah satu faktor penentu kekuatan SEO sebuah website adalah backlink berkualitas dan traffic, dan dengan sosial media bisa mendapatkan kedua hal ini sekaligus. Backlink berkualitas adalah 204nstag link yang menuju ke website berasal dari website dengan kualitas yang baik. Sosial media pada umumnya tergolong sebagai website dengan kualitas yang sangat-sangat baik, hal ini tentu memberi efek positif bagi aspek SEO website. Sama halnya dengan traffic. Jika konten yang dishare di sosial media dinilai menarik oleh pengguna, maka akan mendapatkan banyak traffic dari website yang berkualitas pula. Inilah efek positif tidak langsung dari sosial media terhadap SEO.

Sebelumnya proses pemasaran mengalami kendala untuk menyajikan informasi kepada konsumen dalam waktu yang singkat. Kini dengan adanya sosial media, penyampaian informasi kepada konsumen menjadi lebih mudah dan cepat. Saat menggunakan sosial media untuk bisnis, khususnya untuk membagikan informasi mengenai bisnis, cukup klik tombol 'share' pada setiap sosial media yang digunakan. Ingat, pastikan bahwa informasi yang bagikan sesuai dengan minat target konsumen. Search engine membutuhkan waktu berjam-jam bahkan hari atau minggu agar konten yang baru posting bisa muncul di halaman pencarian. Tidak seperti sosial media yang bisa menampilkan dengan real time. Apapun yang posting di sosial media maka akan langsung muncul di timeline follower, sehingga bisa langsung menghasilkan traffic ke website bahkan penjualan. Hal ini tentunya akan efektif jika akun sosial media memiliki follower yang cukup banyak. Kalaupun tidak, mungkin bisa mempertimbangkan menggunakan jasa influencer.

Sosial media mampu menjangkau siapapun yang menggunakannya, terlepas apakah itu calon konsumen ataupun bisnis lain yang juga membutuhkan jasa atau produk bisnis. Mereka dapat memanfaatkan sosial media dalam melakukan pencarian produk atau jasa yang mereka butuhkan. Kini pengguna smartphone semakin meningkat bersamaan juga dengan akses ke sosial media, alasannya sederhana yakni karena lebih praktis. Begitu pula dengan pencarian produk atau brand, kini konsumen selalu berusaha mencari informasi sebuah brand di sosial media. Hal ini biasanya dilakukan sebelum memutuskan untuk membeli atau menggunakan suatu produk. Konsumen melakukan hal ini untuk mencari tahu reputasi brand di sosial media, seperti berapa banyak follower, seperti apa komentar konsumen lain, informasi produk terbaru dan hal lainnya. Selain untuk melihat reputasi, konsumen juga menggunakan sosial media untuk mengukur seberapa terpercayanya brand. Oleh karena itu sosial media penting, karena berada di salah satu tahap yang mendukung keputusan pembelian konsumen. 
Sosial media merupakan sarana yang sesuai untuk menciptakan hubungan dengan konsumen. Contohnya, sosial media membantu bisnis agen perjalanan wisata untuk berkomunikasi dengan wisatawan. Hubungan dengan konsumen dibangun sebelum, pada saat, dan setelah konsumen menggunakan jasa mereka. 'Sebelum' adalah pada saat calon wisatawan melakukan riset mengenai lokasi wisata/jasa di sosial media. 'Pada saat' adalah 205nstag wisatawan berada di lokasi wisata dan 'setelah' adalah 205nstag wisatawan selesai berwisata dan memosting konten mereka pada saat liburan. Komunikasi semacam ini sangat memungkinkan dilakukan melalui sosial media saat ini dibandingkan hanya melalui pemasaran konvensional.

Terakhir, sosial media membantu bisnis untuk meningkatkan brand awareness dengan biaya yang bisa dibilang 205nstag tidak ada. Biaya yang sangat diperlukan untuk hal ini adalah waktu. Pasalnya membangun brand dengan sosial media setidaknya membutuhkan tenaga, proses dan waktu yang tidak singkat. Meskipun tanpa biaya, yang dimaksud disini adalah 205nstag benar-benar melakukan promosi di sosial media tanpa menggunakan iklan. Hal ini sangat mungkin dilakukan dan hasilnya bisa jauh lebih baik daripada mengandalkan iklan. Harus diingat, membutuhkan konten yang menarik dan berkualitas. Artinya jika memposting foto, membutuhkan foto dengan kualitas baik untuk bisa menarik perhatian calon konsumen.

\section{SIMPULAN}

Berdasarkan hasil penelitian yang telah di lakukan mengenai pengaruh Periklanan sosial media terhadap Keputusan Pembelian konsumen di lingkungan Universitas Bali Internasional. Maka diperoleh beberapa kesimpulan, untuk menjawab beberapa identifikasi masalah pada penelitian ini. Berikut ini, merupakan kesimpulan yang didapat oleh penulis sebagai berikut : (1) Tanggapan responden terhadap Periklanan berada pada kategori baik. Hal ini mengindikasikan bahwa iklan sosial media berpengaruh terhadap keputusan pembelian. Konsumen mengetahui produk melalui Media Sosial. Iklan yang ditayangkan mendapat perhatian dari konsumen karena informasi yang di berikan jelas serta penggunaan bahasa dalam iklan 205nstagram mudah dipahami. Iklan 205nstagram menimbulkan kesan positif sehingga konsumen mampu mengingat Iklan yang ditanyangkan produk dalam waktu yang panjang. (2) Tanggapan responden terhadap keputusan pembelian melalui iklan di 205nstagram berada pada kategori baik. Hal ini mengindikasikan bahwa konsumen melakukan pembelian produk karena sesuai dengan keinginan dan kebutuhan. Pembelian produk di 205nstagram karena sesuai dengan hasil gambar yang diberikan dalam iklan. Banyaknya pesaing membuat konsumen melakukan pemilihan merek sebelum akhirnya membeli produk yang tayang dalam iklan di 205nstagram. Konsumen emilih waktu yang tepat untuk melakukan pembelian produk di 205nstagram dan melakukan pembelian produk di 205nstagram dengan metode pembayaran secara langsung/cash. (3) Melalui perhitungan Uji parsial (Uji t) diperoleh kesimpulan bahwa Periklanan memiliki pengaruh yang signifikan terhadap Keputusan Pembelian. Hal ini terlihat dari nilai $t$ tabel yang diperoleh (lebih besar dari $t$ 
hitung). Hubungan yang terjadi diantara keduanya adalah kuat dengan arah positif. Hal ini mengindikasikan bahwa Periklanan mempunyai pengaruh yang searah dengan Keputusan Pembelian produk di 206nstagram. Dalam hal ini, semakin tinggi Periklanan, maka akan semakin tinggi pula Keputusan Pembelian produk yang dijual di 206nstagram.

Berdasarkan analisis dan pembahasan serta kesimpulan yang diperoleh, ada beberapa saran yang diajukan oleh penulis kepada pihak-pihak yang terkait dalam penelitian ini, diantaranya adalah saran bagi Perusahaan yang menjual produk di Instagram yaitu (a) Perusahaan yang menjual produk di 206nstagram diharapkan bisa meningkatkan periklanan melalui 206nstagram ads di 206nstagram dan juga facebook. Karena saat ini media sosial tidak luput dari keseharian masyarakat dan merupakan media periklanan terbaik (b) Perusahaan yang menjual produk di 206nstagram diharapkan bisa lebih kreatif dan inovatif dalam menyampaikan pesan dalam iklan serta menggunakan bahasa yang mudah dipahami. Karena iklan yang disampaikan akan sangat berpengaruh terhadap konsumen yang melihat/mendengarnya. Perusahaan yang menjual produk di 206nstagram diharapkan bisa menyesuaikan kebutuhan iklan di masyarakat supaya iklan mengenai produk tersebut bisa diterima dengan baik. Bagi yang akan meneliti mengenai faktor-faktor yang bisa mempengaruhi Keputusan Pembelian, dapat dilakukan dengan menambahkan variabel independen lainnya seperti kualitas pelayanan, harga, kepuasan pelanggan, minat beli, promosi, citra merek, dan pengalaman pelanggan.

\section{REFERENSI}

Abdullah, M.Ma'ruf.(2017). Manajemen Komunikasi Periklanan. Aswaja Pressindo, Yogyakarta.

Andriani, Dewi. (2018). Cellum Bidik Potensi Bisnis Mobile Wallet di Indonesia. Retrieved February 28, 2019, from https://ekonomi.bisnis.com/read/20181204/105/866035/cellum-bidikpotensi-bisnis-mobile-wallet-di-indonesia

Ar-Robi, Muhammad Ridho dan Berto Mulia Wibawa. 2019. Analisis Tingkat Kepuasan dan Performa pada Merchant OVO di Surabaya. Jurnal sains dan seni its vol. 8, no. 1 (2019), 2337-3520 (2301-928x print).

Gardner, Christina dan Donald L Amoroso. (2004). Development of an Instrument to Measure the Acceptance of Internet Technology by Consumers. Proceedings, Hawaii International Conference on System Sciences. 37. Hlm. $1-10$.

Goyette, I., Ricard, L., \& Bergeron, J. (2010). e-WOM Scale: Word-of-Mouth Measurement Scale for e-Services Context *. 23, 5-23.

Handayani, dkk. 2007. Studi Korelasi Motivasi Pengguna dan Pemanfaatan Koleksi CD-ROM di UPT Pusat Perpustakaan UII Yogyakarta. Jurnal 
Berkala Ilmu Perpustakaan dan Informasi.Vol III no. 7.Yogyakarta.Universitas Gadjah Mada.

Jatmiko, B. P. (2018). Fintech Sumbang Rp 25,97 Triliun ke Perekonomian Nasional - Kompas.com. Retrieved November 22, 2018, from https://ekonomi.kompas.com/read/2018/08/28/150923726/fintechsumbang-rp-2597-triliun-ke-perekonomian-nasional

Jogiyanto. (2008). Sistem Informasi Keperilakuan. yogyakarta: Andi.

Kim, Yonghee, Young-Ju Park, Jeongil Choi \& Jiyoung Yeon. 2015. An Empirical Study on the Adoption of Fintech Service: Focus on Mobile Payment Service. Advanced Science and Technology Letters, 114, 136-140

Kotler, P., \& Armstrong, G. (2017). Prinsip-Prinsip Pemasaran (12 jilid 1). Jakarta: Erlangga.

Kotler, P., \& Keller. (2013). Manajemen Pemasaran (13th ed.). Jakarta: Erlangga.

Kotler, P., \& Keller, K. L. (2016). Marketing Management (15th ed.). Pearson Education,Inc.

Morisson M.A. (2015). Periklanan komunikai Pemasaran Terpadu. Jakarta: Prenadamedia Group.

Samosir, Ris Susanty. 2008. Analisis Biaya Satuan Persalinan Dengan Metode Activity-Based Costing (ABC) Sebagai Dasar Usulan Tarif Di Puskesmas Perawatan Karang Mulia Kabupaten Nabire-Papua. Program Studi Ilmu Kesehatan Masyarakat Jurusan Ilmu-Ilmu Kesehatan Program Pasca Sarjana Fakultas Kedokteran Universitas Gadjah Mada Yogyakarta

Sekaran, Uma dan Bougie, Roger. 2013. Research Methods for Business. United Kingdom: Jhon Wiley \& Sons Ltd.

Sudigdo;, S., \& S., I. (2008). Dasar Dasar Metodologi Penelitian Klinis (III). Jakarta: CV Sagung Seto.

Sugiyono. (2015). Metode Penelitian dan Pengembangan. Bandung: Alfabeta.

Suyanto, Taufan Adi Kurniawan. Faktor yang Mempengaruhi Tingkat Kepercayaan Penggunaan FinTech pada UMKM Dengan Menggunakan Technology Acceptance Model (TAM). Jurnal Akuntansi \& Manajemen Akmenika Vol. 16 No. 1.

Tan, M. and Teo, T.S.H. 2000.Factors influencing the adoption of internet banking, Journal of the Association for Information Systems, Vol. 1 No. 1,pp. 1-42. 
Kadek Riyan Putra Richadinata, Pengaruh Iklan Sosial...

Tjiptono, F. (2015). Strategi Pemasaran (4th ed.). yogyakarta: Andi.

Wibowo. (2011). Manajemen Kinerja. yogyakarta: Raja Grafindo Persada.

Yuniarti, Veronica. 2019. Faktor - Faktor Yang Memengaruhi Minat Penggunaan Financial Technology Peer To Peer Lending. Uknown. 